\title{
On the trade-offs and synergies between forest carbon sequestration and substitution
}

\author{
Sampo Soimakallio ${ }^{1}$ (D) $\cdot$ Tuomo Kalliokoski $^{2} \cdot$ Aleksi Lehtonen $^{3} \cdot$ Olli Salminen $^{3}$
}

Received: 30 August 2018 / Accepted: 25 January 2021 / Published online: 12 March 2021

(C) The Author(s) 2021

\begin{abstract}
Forest biomass can be used in two different ways to limit the growth of the atmospheric greenhouse gas (GHG) concentrations: (1) to provide negative emissions through sequestration of carbon into forests and harvested wood products or (2) to avoid GHG emissions through substitution of non-renewable raw materials with wood. We study the trade-offs and synergies between these strategies using three different Finnish national-level forest scenarios between 2015 and 2044 as examples. We demonstrate how GHG emissions change when wood harvest rates are increased. We take into account $\mathrm{CO}_{2}$ and other greenhouse gas flows in the forest, the decay rate of harvested wood products and fossilbased $\mathrm{CO}_{2}$ emissions that can be avoided by substituting alternative materials with wood derived from increased harvests. We considered uncertainties of key parameters by using stochastic simulation. According to our results, an increase in harvest rates in Finland increased the total net GHG flow to the atmosphere virtually certainly or very likely, given the uncertainties and time frame considered. This was because the increased biomass-based $\mathrm{CO}_{2}$ and other greenhouse gas emissions to the atmosphere together with decreased carbon sequestration into the forest were very likely higher than the avoided fossil-based $\mathrm{CO}_{2}$ emissions. The reverse of this conclusion would require that compared to what was studied in this paper, the share of long-living wood products in the product mix would be higher, carbon dioxide from bioenergy production would be captured and stored, and reduction in forest carbon equivalent net sink due to wood harvesting would be minimized.
\end{abstract}

Keywords Forest $\cdot$ Carbon $\cdot$ Sequestration $\cdot$ Substitution $\cdot$ Sink $\cdot$ Avoided emissions

Sampo Soimakallio

sampo.soimakallio@ymparisto.fi

1 Finnish Environment Institute SYKE, Mechelininkatu 34a, P.O. Box 140, FI-00251 Helsinki, Finland

2 University of Helsinki, Latokartanonkaari 7, P.O. Box 27, FI-00014 Helsinki, Finland

3 Natural Resources Institute Finland (Luke), Latokartanonkaari 9, FI-00790 Helsinki, Finland 


\section{Introduction}

The Paris Agreement aims to stabilize the global mean temperature increase to a well-below $2{ }^{\circ} \mathrm{C}$ compared to the pre-industrial level (UNFCCC 2015). According to current scientific knowledge, the achievement of the particular target would require deep cuts in global greenhouse gas (GHG) emissions and an increase in carbon sinks over the next few decades in order to have GHG emissions and sinks in balance, i.e. net GHG emissions zero by 2050 (Rockström et al. 2017). Even if the global GHG emissions are reduced close to zero within a few decades, the carbon sinks must remain at least at the current level (approximately $4 \mathrm{Gt} \mathrm{C}$

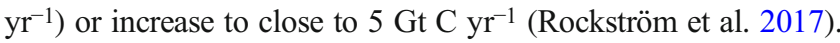

If we are able to restrict global GHG emissions in accordance with the Paris Agreement target, we will still have the challenge with carbon sink permanence. The fate of natural carbon sinks, namely ocean and biosphere, is highly uncertain in the future. Stabilization or decline in atmospheric $\mathrm{CO}_{2}$ concentrations, a requirement of achieving a well-below $2{ }^{\circ} \mathrm{C}$ target, will possibly also reduce $\mathrm{CO}_{2}$ fertilization and dissolving. They have been one of the most significant contributors to existing carbon sinks (Rockström et al. 2017). Consequently, it is likely that the achievement of well-below $2{ }^{\circ} \mathrm{C}$ will require an increase in purposely made carbon sinks. These so-called negative emission technologies include bioenergy combined with carbon capture and storage (BECCS), direct air capture (DAC) and improved land management (Smith et al. 2016). All negative emission technologies are subject to significant scientific and political uncertainties (Anderson \& Peters 2016). The most mature strategies to increase sinks are improved land stewardship, including reforestation, afforestation and natural forest management (Field and Mach 2017; Griscom et al. 2017; Shukla et al. 2019).

Forest biomass can be used in two different ways to limit the growth of the atmospheric $\mathrm{CO}_{2}$ concentrations: (1) to provide negative emissions through sequestration of carbon into forests and harvested wood products or (2) to avoid $\mathrm{CO}_{2}$ emissions through substitution of non-renewable materials and energy with wood (Pingoud et al. 2010; Helin et al. 2013; Kallio et al. 2013; Cowie et al. 2019). Carbon is sequestered into forests in net ecosystem production (NEP) which is the difference between gross primary production and total ecosystem respiration (Lovett et al. 2006). The more powerful is the net primary production (NPP); the more carbon is sequestered into forests in the absence of disturbances. In managed forests, the growth of trees over time is maximized when the current annual increment is equal to the mean annual increment of forests (e.g. Assmann 1970). However, increased harvesting of trees typically increases biomass-based carbon dioxide in the atmosphere. This is due to decreased sequestration of carbon in trees, increased carbon dioxide emissions from decay of litter and soil organic carbon. In addition, only part of the carbon harvested from the forest remains adequately long in harvested wood products. On the other hand, wood harvested can be used in place of non-renewable raw materials, thus decrease the generation of fossil-based $\mathrm{CO}_{2}$ emissions.

In Finland, forests cover about 22.8 million hectares of the land area of 30.4 million hectares (Luke 2019a), forest land area corresponding to 14\% of that in the EU28 (Forest Europe 2015). Finnish forests are relatively young and in well-growing age (Forest Europe 2015). In Finland, forests act both as a significant net carbon sink (i.e. GHG removals are higher than emissions) and provide a significant amount of wood to society. Between 1990 and 2017, the annual national net carbon equivalent sink of Finnish forest land varied between 5 and 13 Mt C-eq., including $\mathrm{CO}_{2}$ and methane $\left(\mathrm{CH}_{4}\right)$ and nitrous oxide $\left(\mathrm{N}_{2} \mathrm{O}\right)$ balances from living biomass, soil organic matter and dead organic matter (Statistics Finland 2019a). The 
fluctuation was mainly due to changes in annual commercial roundwood fellings varying from 40 million cubic metres (1991) to $72 \mathrm{Mm}^{3}$ (2017), affected mainly by the international market of forest industry products (Luke 2019b). The most recent national information about development of forest resources indicates that roundwood harvest rates can be increased up to 84 million cubic metres annually $\left(\mathrm{Mm}^{3} \mathrm{yr}^{-1}\right)$ by 2024 and up to $93 \mathrm{Mm}^{3} \mathrm{yr}^{-1}$ by 2034 without turning national forests from net carbon equivalent sink to the source (Luke 2018). Thus, harvest rates equal or lower than those would keep standing tree stock increasing in Finland. National forest strategy of Finland 2025 aims to increase the roundwood harvest rates up to $80 \mathrm{Mm}^{3} \mathrm{yr}^{-1}$ by 2025 (MMM 2019).

In this paper, the trade-offs and synergies between negative $\mathrm{CO}_{2}$ emissions through sequestration and avoided $\mathrm{CO}_{2}$ emissions through increased wood use for substitution of fossil-based emissions are studied. We use three recent Finnish national-level wood harvest scenarios between 2015 and 2044 as examples. We demonstrate how biomass-based $\mathrm{CO}_{2}$ emissions change when wood harvest rates are increased. In addition, we assess how much fossil-based $\mathrm{CO}_{2}$ emissions can be avoided by substituting alternative materials with wood derived from increased harvests. We also take into account non- $\mathrm{CO}_{2} \mathrm{GHG}$ fluxes in forest land. In the end, we discuss how the possibilities to avoid the generation of biomass-based $\mathrm{CO}_{2}$ emissions through increasing the share of long-living wood products and BECCS influence the results.

\section{Material and methods}

\subsection{Calculation of the atmospheric carbon dioxide equivalent balances}

We calculate the atmospheric carbon dioxide equivalent balances first in absolute terms for the three different scenarios studied and second as a difference between scenarios. The absolute $\mathrm{CO}_{2}$-eq. balances are calculated deterministically using default values for each of the input variables. As the key focus in the paper is on the differences in the atmospheric $\mathrm{CO}_{2}$-eq. balances between the scenarios, we study the uncertainty of the results applying stochastic simulation for certain key input variables, i.e. net forest carbon (equivalent) sink and carbon stock change of harvested wood products and avoided $\mathrm{CO}_{2}$-eq. emissions in material and energy substitution. We applied Monte Carlo simulation (10,000 runs) which provides a probability distribution for each output functions using MS Excel add-in software @ Risk. For each stochastic parameter, we assumed non-skewed triangular distribution.

The modelling approach and assumptions used are described in more detail in the following sub-sections. To characterize the probabilities of our results, we used the IPCC terminology (see IPCC 2014).

\subsection{MELA model coupled with GHG inventory methods}

The three different forest scenarios studied were based on those compiled for a background study on the Finnish National Energy and climate strategy for 2030 (Lehtonen et al. 2016; Tuomainen et al. 2017). In those scenarios, the development of Finnish forests was estimated using a large-scale forest planning tool called MELA (version MELA2012) (Redsven et al. 2013) with the sample plot data of the 11th Finnish national forest inventory (NFI11) measured in the years 2009-2013 (Korhonen 2016). The carbon calculation of the trees was 
based on the biomass functions of Repola $(2008,2009)$ embedded in MELA. MELA results concerning the amount of litter from living trees, harvesting residues and natural mortality were used as inputs for calculating changes in soil carbon stocks using the Yasso07 model (Tuomi et al. 2011) for mineral soils and a method based on emission factors (Minkkinen et al. 2007; Ojanen et al. 2010) for organic soils (see Sievänen et al. 2014).

The approach adopted in MELA is based on integrated stand-level simulation and forest area level optimization (Siitonen et al. 1996). The MELA simulator consists of empirical treelevel models for ingrowth, growth and mortality (Hynynen et al. 2002) and of a set of standlevel human actions which follow the Finnish forest management recommendations. In MELA2012, tree-wise basal-area growth models have been calibrated using growth measurement data from the NFI8. In this study, these basal-area growth models were calibrated with sample tree measurements from the NFI11. The growth measurements of the NFI11 were adjusted with growth indices to the average level of diameter increment for the years 19842013. The applied method is conservative though it resulted in higher increment; it did not take into account the climate change since the mid-year (1999) of the period.

From the ample set of simulated management schedules, linear optimization software (Lappi 1992) embedded in MELA selects the ones which optimize the user-specified region level objective function subject to a set of given constraints. In this study, the objective function was net present value using a $4 \%$ interest rate. In addition, scenario-specific constraints were applied. The modelling time frame of the scenarios was 30 years (2015-2044).

\subsection{Scenarios studied}

The business as usual (BAU) scenario assumed that the domestic industrial wood use equals to the levels of domestic wood use of the years 2013-2014, added by $5 \mathrm{Mm}^{3} \mathrm{yr}^{-1}$ required by those new forest industry investments that had been already decided and currently running (i.e. Äänekoski bioproduct mill). In the BAU scenario, the amount of forest industries' roundwood harvested was $61 \mathrm{Mm}^{3} \mathrm{yr}^{-1}$. The energy use of forest chips increased from 7.8 to $13.5 \mathrm{Mm}^{3} \mathrm{yr}^{-1}$ by 2020 in accordance with the target set in the National Energy and Climate strategy for 2030 (TEM 2017). Household firewood use remained at the current level of $6 \mathrm{Mm}^{3} \mathrm{yr}^{-1}$, and this is included in stemwood for direct energy use figures in Table 1. Total roundwood removals in this scenario were estimated to be about $73 \mathrm{Mm}^{3} \mathrm{yr}^{-1}$ from 2020 onwards ( $72 \mathrm{Mm}^{3} \mathrm{yr}^{-1}$ on the average between 2015 and 2044 as shown in Table 1). The increase in harvest rates from the level of 2013-2014 is mainly targeted to thinnings.

The policy scenario (POL) differed from the BAU scenario by the loggings of roundwood. Timber harvesting increased in this scenario up to $68 \mathrm{Mm}^{3} \mathrm{yr}^{-1}$ by 2035 based on the survey of

Table 1 Average annual harvest rates of sawlogs, pulpwood, stemwood for direct energy use and forest residues in BAU, POL and MSY scenarios over 2015-2044 $\left(\mathrm{Mm}^{3} \mathrm{yr}^{-1}\right)$

\begin{tabular}{llll}
\hline Scenario & BAU & POL & MSY \\
\hline Saw logs & 24.0 & 28.0 & 35.5 \\
Pulp wood & 36.5 & 38.5 & 42.5 \\
Stemwood for direct energy use & 11.5 & 11.0 & 8.0 \\
Total roundwood harvests (forest industries' and energy) & 72.0 & 77.5 & 86.0 \\
Forest residues (branches, tops, stumps) & 7.0 & 8.0 & 9.0 \\
Total wood harvests (roundwood and forest residues) & 79.0 & 85.5 & 95.0 \\
\hline
\end{tabular}


the production of the Finnish forest industry (Pöyry Management Consulting 2016). The energy use of wood chips and the households' firewood use evolved like in BAU based on the target set in the National Energy and Climate strategy for 2030 (TEM 2017). The total roundwood removals were at the level of $80 \mathrm{Mm}^{3} \mathrm{yr}^{-1}$ since 2025. The increase in harvest rates compared to the BAU scenario is mainly derived from final fellings.

The maximum sustainable yield (MSY) scenario assumed that the level of harvesting follows the definition of maximum sustainable yield of Natural Resources Institute of Finland, where timber harvests and net revenues are not allowed to decline between the subsequent periods which in our study were 2015-2024, 2025-2034 and 2035-2044. The amount of harvested timber and energy wood was around $90 \mathrm{Mm}^{3} \mathrm{yr}^{-1}$ from 2025 (Lehtonen et al. 2016; Tuomainen et al. 2017). This was based on the optimal solutions of the MELA model to maximize net revenues under the given constraints. Increased supply of sawlogs and pulpwood resulted in decreased supply of stemwood for direct energy use in MSY compared to BAU and POL. In MSY, the final felling area was significantly higher while the thinning area was lower compared to BAU and POL scenarios.

In all of these scenarios, we assumed that the annual harvest of stumps for energy can be at a maximum of $1 \mathrm{Mm}^{3} \mathrm{yr}^{-1}$. Simulation of forest management choice was based on Forest management guidelines 2013 (Äijälä et al. 2014). Simulations were carried out on all forest land and poorly productive forest land but forest management was possible only on forest land available for wood supply and on forest land available for restricted wood supply where clear fellings were not allowed (Lehtonen et al. 2016).

All approximations for climate change impacts into forest growth and soil organic matter decomposition were excluded. Estimated scenarios include soil carbon stock change estimates and also GHG emissions of $\mathrm{N}_{2} \mathrm{O}$ and $\mathrm{CH}_{4}$ from forest land. Non- $\mathrm{CO}_{2}$ GHG emissions were converted into carbon dioxide equivalents using global warming potential $\left(\mathrm{GWP}_{100}\right)$ figures from IPCC AR4 (Table 2.14 in Foster et al. 2007) which are 25 for $\mathrm{CH}_{4}$ and 298 for $\mathrm{N}_{2} \mathrm{O}$. Impact of fertilization, forest fires, residue burning and land-use change for the climate was excluded. Concerning the scenarios in question, there were no specific policy measures in connection to scenarios or with respect to different harvesting levels for increasing fertilization, afforestation or residue burning. Based on historical data of forest fires, there was neither reason for anticipating differences between the scenarios in the studied time frame.

In this paper, we show the results following the physical flows of carbon dioxide equivalents as they are assumed to occur. This means that biomass-based $\mathrm{CO}_{2}$ emissions are reported as they are assessed to take place and removals by forest carbon sequestration is determined by the growth of trees. As a result, the atmospheric $\mathrm{CO}_{2}$ balance is the same than by following the accounting principles of greenhouse gas inventories set by the IPCC, where biomass-based $\mathrm{CO}_{2}$ emissions are reported as zero in the energy sector and stock changes in forest and harvested wood product pools are reported instead of physical $\mathrm{CO}_{2}$ flows (IPCC 2019).

The uncertainty in the latest statistics of forest carbon net sink in Finland is estimated to be approximately $\pm 30 \%$ (Statistics Finland 2019a). It can be assumed that this uncertainty is higher in the scenarios, in particular, as the development of the growth of trees and variables influencing soil GHG balances are subject to uncertainties. On the other hand, it can be assumed that the uncertainty involved in many of the parameters influences the results in the same direction, i.e. there is a strong positive correlation between many of the parameters. When calculating the differences in the atmospheric $\mathrm{CO}_{2}$-eq. balances between the scenarios, we assumed $\pm 40 \%$ uncertainty range as $95 \%$ confidence interval for and strong positive correlation $(\rho=0.9)$ between the forest carbon net sink of the scenarios. 


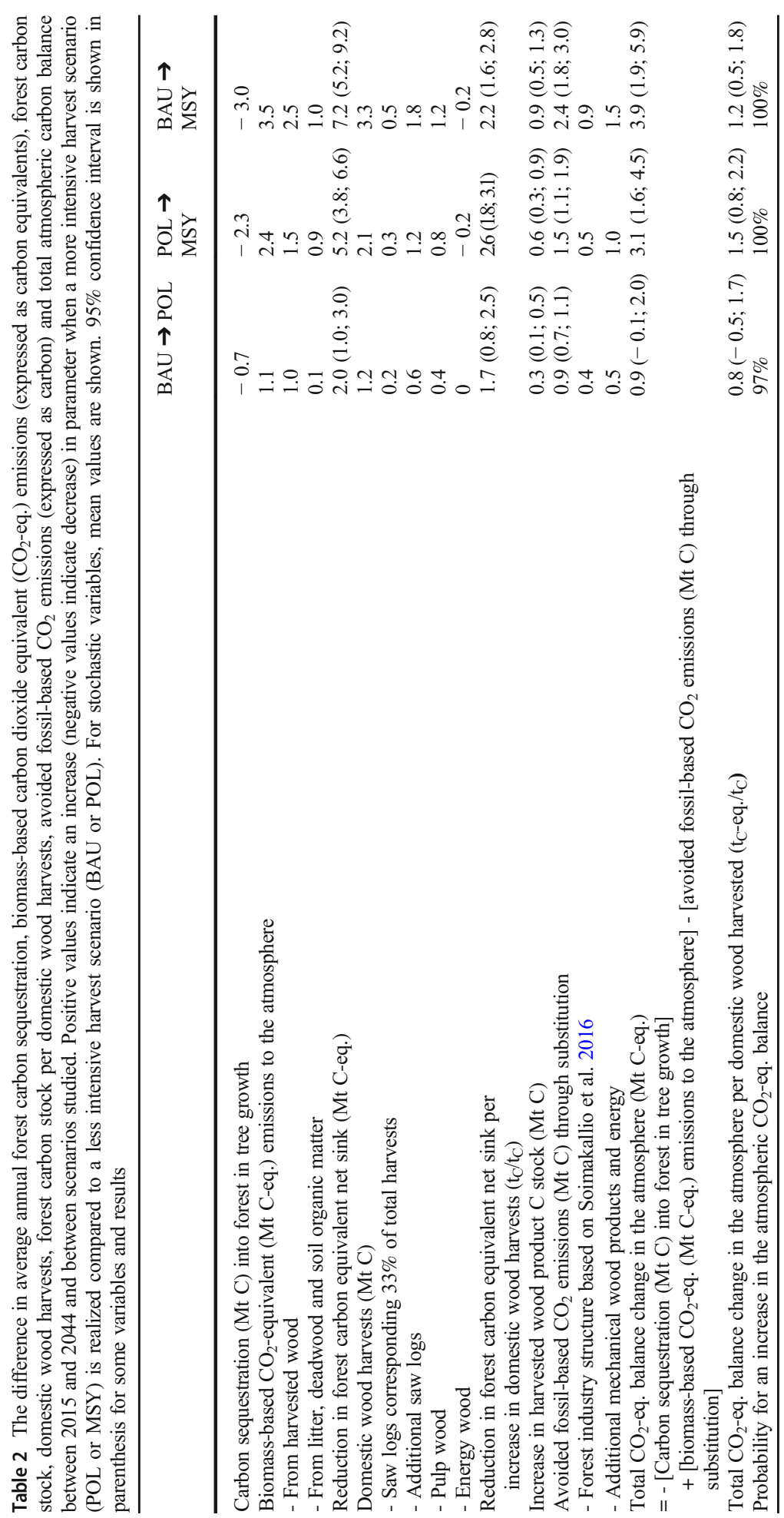




\subsection{Assumptions on avoided emissions}

When harvests are increased, materials and energy from additional harvests can be used in place of alternative materials and energy serving the same function. Thus, substitution credits from emissions avoided are generated between two scenarios (Soimakallio et al. 2016, Cowie et al. 2019). Here we refer with the avoided emissions to fossil $\mathrm{CO}_{2}$ emissions (from fossil fuel use and industry) avoided in substitution. Biomass-based $\mathrm{CO}_{2}$ flows related to changes in forest and HWP carbon stocks are considered separately and not included in avoided emissions in order to avoid double counting of biomass-based $\mathrm{CO}_{2}$ emissions. The avoided emissions are expressed as a dimensionless indicator based on a ratio between fossil $\mathrm{CO}_{2}$ emissions avoided (in tonnes of C) and wood harvested entering the system (in tonnes of C).

When wood is harvested from the forest, it is processed into various types of end-products which are used by society. Processing requires materials and energy which result in $\mathrm{CO}_{2}$ emissions. Part of the energy requirement is covered by wood harvested (Rüter et al. 2016, Lippke et al. 2011). The rest is covered by various types of energy sources including fossil fuels. The direct fossil fuel-based energy requirement and that embodied in the production of auxiliary materials reduces the amount of fossil $\mathrm{CO}_{2}$ emissions avoided in substituting for alternative materials with wood (Soimakallio et al. 2016).

According to a number of studies, more GHG emissions may be avoided in construction material substitution than in energy substitution (Gustavsson et al. 2006; Pingoud et al. 2010; Sathre and O'Connor 2010; Soimakallio et al. 2016). This is the case, in particular, if fossil fuel-intensive materials are assumed to be replaced and if harvested wood products are assumed to be used as energy at the end of life to further replace fossil fuels. However, considering the uncertainties in processing and related emissions of both wood and alternative products to be replaced, the avoided emissions are not necessarily the highest in scenarios where the share of mechanical wood products is the highest (Soimakallio et al. 2016). New products from pulpwood, such as bio-composites, may avoid more fossil $\mathrm{CO}_{2}$ emissions in material substitution than mechanical wood products or traditional paper products (Hurmekoski et al. 2018; Seppälä et al. 2019).

Scenarios studied in Soimakallio et al. (2016) reflect a continuation of 2010 wood utilization and five different hypothetical forest industry structures presented in Kallio et al. (2014). The share of saw logs out of the overall domestic harvests in these scenarios are very well in line with our BAU, POL and MSY scenarios: BAU corresponds to Kallio et al. (2016) Base scenario, POL corresponds to Kallio et al. (2016) Stagnation scenario and MSY corresponds to Continuation of 2010 wood utilization. However, as the avoided emissions were calculated for the overall wood utilization (in comparison to no harvest scenario) in Soimakallio et al. (2016), such data is not directly applicable to describe changes between our scenarios (i.e. between BAU and POL, POL and MSY and BAU and MSY) where the share of mechanical wood products is significantly increased.

In five out of six scenarios studied by Soimakallio et al. (2016), the share of sawlogs from the total domestic harvests is close to one-third. Instead, changes between BAU and POL (Fig. 1a, 1b), POL and MSY (Fig. 1b, 1c) and BAU and MSY (Fig. 1a, 1c) correspond to the share of more than two-thirds. We assessed the avoided emissions between our scenarios in two steps. First, we assessed how much fossil $\mathrm{CO}_{2}$ emissions are avoided on average by a unit of carbon in harvested wood entering the system as presented in Soimakallio et al. (2016). This data was then applied to the change in pulpwood, energy wood and that amount of saw logs that corresponds to the share of one-third in total harvests. In other words, we assumed that the 
2

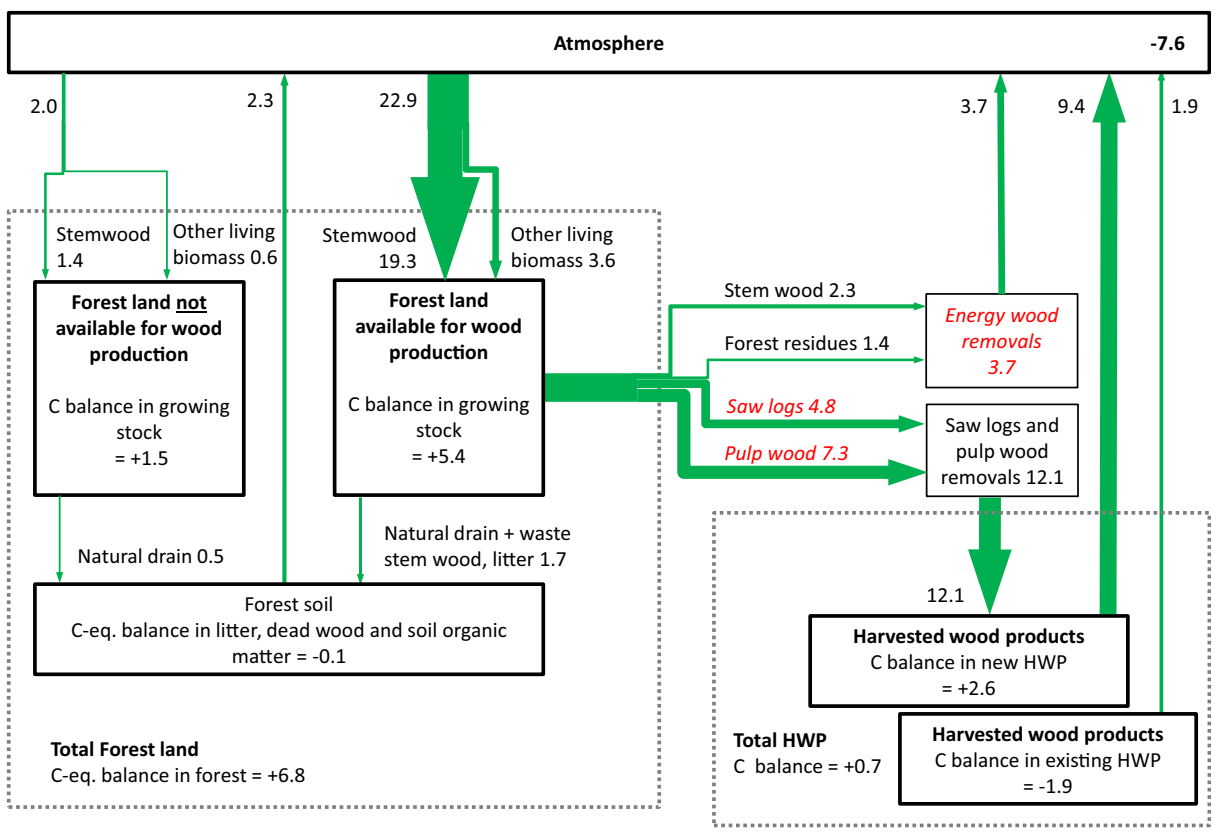

b

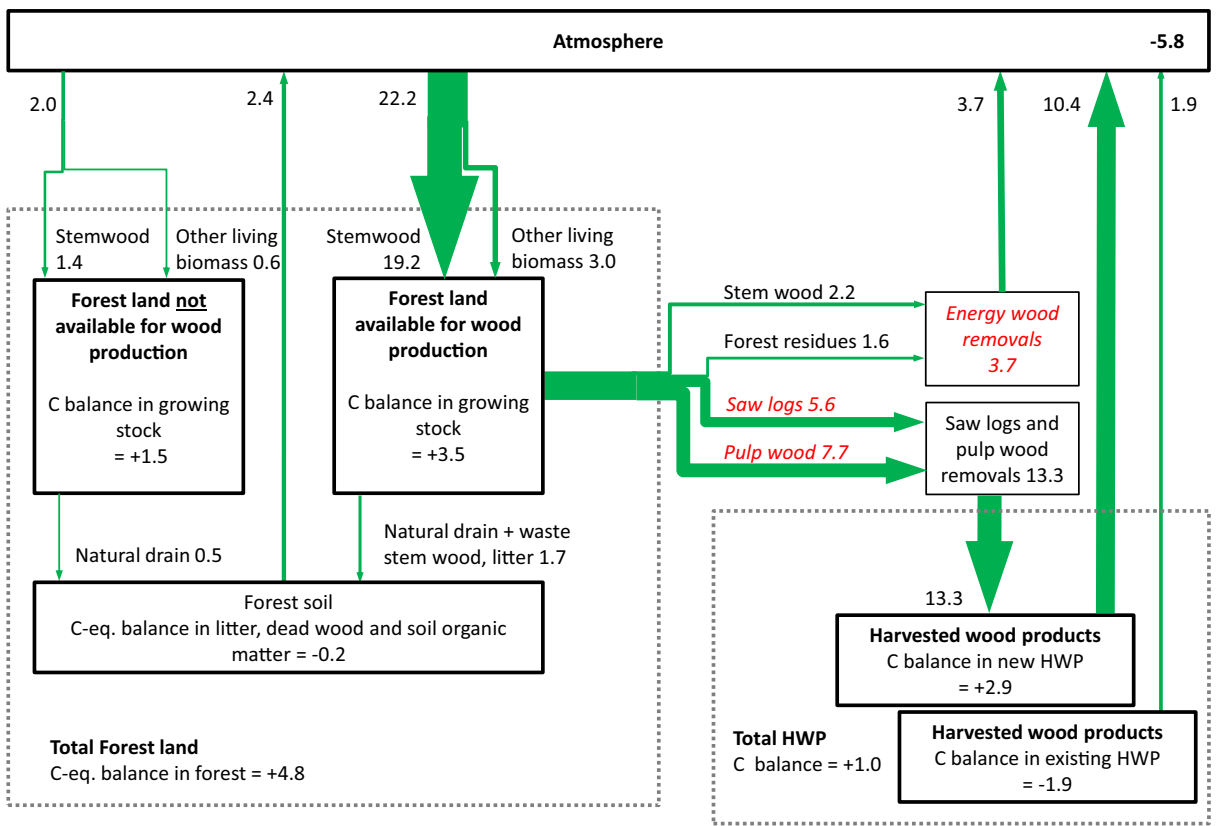

Fig. 1 a, b and c Average annual carbon equivalent balance (Mt C-eq. yr $^{-1}$ ) between 2015 and 2044 of Finnish forests and domestically harvested wood products (HWP) in BAU (a), POL (b) and MSY (c) scenarios. Forest carbon stock is separated into standing tree stock in forest land available and not available for wood production and into forest soil. Flows fixed as input parameters in the modelling appear as red font 
C

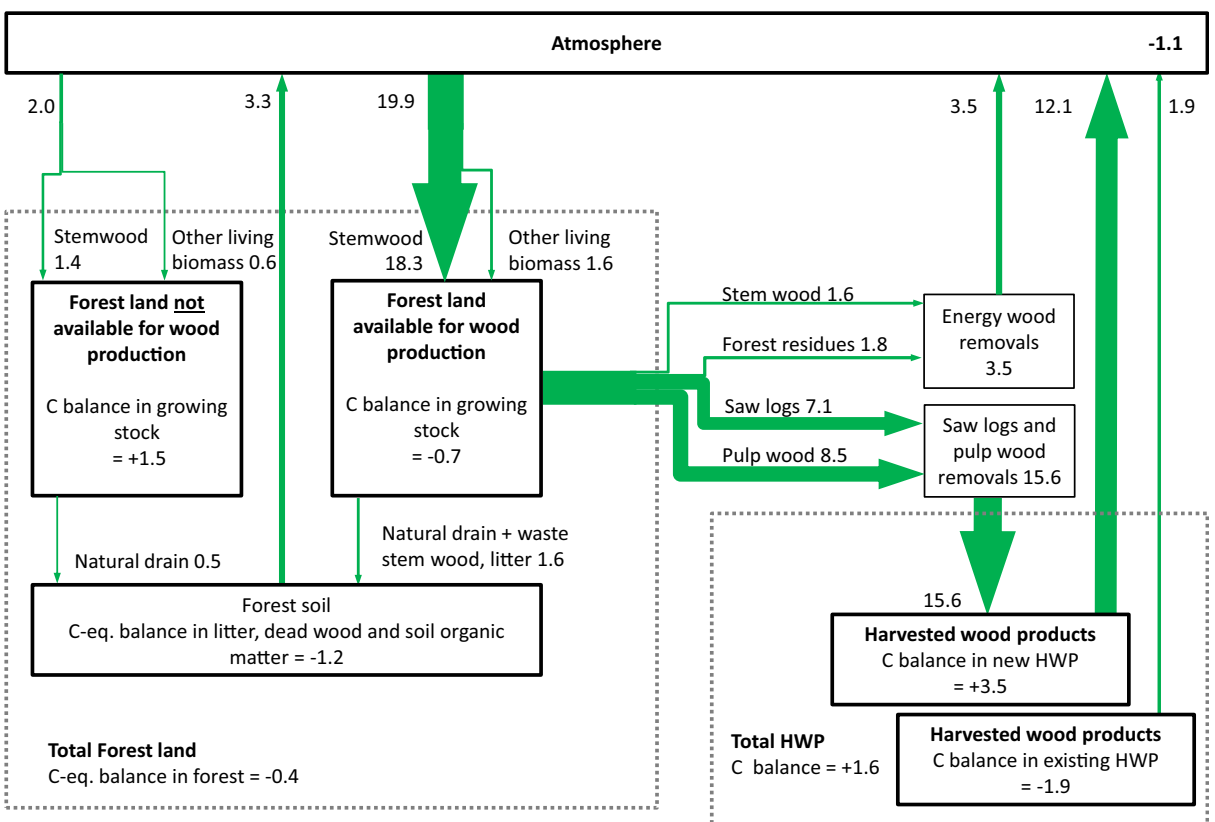

Fig. 1 (continued)

change in wood harvesting between our scenarios partly corresponds to the change in forest industry structures studied by Soimakallio et al. (2016) in their five out of six scenarios (excluding their Change scenario). For the additional increase in sawlog harvesting, we assumed that $50 \%$ is converted to mechanical wood products and $30 \%$ to sawmill residues used for energy to substitute fossil fuels. These assumptions were based on the following: (1) in 2018, the amount of mechanical wood products produced in Finland corresponded to approximately $50 \%$ of the domestic sawlog use (Luke 2020a, b) and (2) the energy consumption of mechanical wood products processing corresponded roughly $20 \%$ of the energy content of mechanical wood products (Statistics Finland 2019a, b), thus only 30\% were considered to be available for substitution.

The probability distributions for the avoided fossil $\mathrm{CO}_{2}$ emissions were determined as follows. We calculated the average unit of fossil $\mathrm{CO}_{2}$ emissions (expressed as tonnes of carbon) avoided per unit of carbon (tonnes of carbon) harvested using the data presented by Soimakallio et al. (2016) for their five scenarios (excl. their Change scenario). For the calculation, we applied the probability distributions of their input variables including various types of material, energy and emission conversion and substitution factors related to wood processing and use (see Soimakallio et al. 2016 for details). The mean values simulated were between 0.5 and $0.6\left(\mathrm{t}_{\mathrm{C}} / \mathrm{t}_{\mathrm{C}}\right)$, and the minimum $2.5 \%$ :ile value was 0.4 and the maximum 97\%:ile value was 0.8 for all the five scenarios. We set 0.6 as the mean value and $\pm 33.3 \%$ uncertainty as a $95 \%$ confidence interval for the particular variable. For the avoided emissions of using additional mechanical wood products, we applied $1.25\left(\mathrm{t}_{\mathrm{C}} / \mathrm{t}_{\mathrm{C}}\right)$ as mean value and \pm 
$60 \%$ uncertainty as a $95 \%$ confidence interval based on Soimakallio et al. (2016). For the additional sawmill residues, the corresponding figures were 0.75 and $\pm 33.3 \%$.

\subsection{Decay of harvested wood products}

We estimated the decay of harvested wood products (HWP) using the methods applied in Finnish national greenhouse gas inventories to the UNFCCC (Statistics Finland 2019a). The method applied is so-called Production approach which encompasses domestically produced HWP originating from domestic harvest. The half-lives applied for coniferous sawnwood, wood-based panels and pulp were 35a, 25a and 2a, and carbon density $\left(\mathrm{t} \mathrm{Cm}^{-3}\right)$ was 0.225 , 0.269 and 0.45, respectively (Statistics Finland 2019a).

We separated the decay of carbon stock in existing HWPs which have been produced before 2015 from the change in the carbon stock of HWPs assumed to be produced in the studied scenarios between 2015 and 2044. The average annual emissions from the decay of the HWP stock existing at the beginning of 2015 were assumed to equal 1.9 Mt C between 2015 and 2044 (Ollila 2017). The change in HWP stock due to domestic harvests between 2015 and 2044 was calculated based on the forest scenario activity data. Based on the current situation, $43 \%$ and $7 \%$ of the carbon content of saw logs harvested were assumed to be converted into end-products for coniferous sawnwood and wood-based panels.

The uncertainty of HWP carbon stock changes applied in the latest GHG inventory is $\pm 50 \%$ (Statistics Finland 2019a). Like with the forest carbon net sink, it can be assumed that the uncertainty involved in HWP carbon stock changes influences the results of various scenarios in the same direction. When calculating the atmospheric carbon dioxide equivalent balances of HWPs between scenarios, we applied $\pm 50 \%$ uncertainty as a $95 \%$ confidence interval and a strong positive correlation $(\rho=0.9)$ for harvested wood product carbon stock changes between scenarios.

\section{Results}

The annual average carbon dioxide equivalent balances in absolute terms between 2015 and 2044 in the studied forest scenarios are presented in Fig. 1a, 1b and 1c. The forest carbon stock increased in BAU and POL scenarios while remained approximately stable in the MSY scenario. As was expected, forest carbon stock became lower the more wood was harvested. Carbon sequestration into forests decreased when harvest rates were increased (Fig. 1a, 1b 1c, Table 2). In addition, biomass-based carbon dioxide and other GHG emissions to the atmosphere were largest in MSY (Fig. 1c) and smallest in BAU (Fig. 1a). This is because roughly half of the increased carbon harvested from forests was released to the atmosphere within the studied period in energy use and decay of harvested wood products (Fig. 1a, 1b, 1c, Table 2).

Increased harvests provided an increased amount of wood for material and energy substitution. The avoided fossil $\mathrm{CO}_{2}$ emissions were the larger the more wood on average was harvested (Table 2). However, the overall GHG balance in the atmosphere was very likely increased when wood harvest rates were increased (Table 2). Given the uncertainty ranges and time frame considered, this is because the avoided fossil $\mathrm{CO}_{2}$ emissions were very likely lower in all the comparisons than the joint effect of the increased biomass-based $\mathrm{CO}_{2}$-eq. emissions to the atmosphere and reduced carbon sequestration into forests (Table 2). The only comparison between BAU and POL scenarios showed a small probability (3\%) that the atmospheric carbon dioxide equivalents were reduced when harvest rates were increased (Table 2). 


\section{Discussion}

\subsection{Interpretation of the results}

Comparison of various wood harvest scenarios showed that when harvest rates were increased, less carbon was stored in the forest over a 30-year time horizon simulated. On average, one additional unit of carbon harvested from forest reduced forest carbon net sink by approximately two units. This implies that the potential to generate negative emissions through sequestration of carbon into the forest was heavily reduced by wood harvests. Even if all the biomass-based $\mathrm{CO}_{2}$ emissions from increased wood harvested could be prevented using BECCS and/or by other means, the atmospheric $\mathrm{CO}_{2}$ balance would not necessarily reduce within the time horizon considered. This is because forgone carbon sequestration was in the same order of magnitude as the avoided fossil-based $\mathrm{CO}_{2}$ emissions (Table 2). In addition, increased harvest rates resulted in increased GHG emissions from litter, deadwood and soil organic matter over the studied time horizon.

Compared to the BAU scenario, the reduction in forest carbon equivalent net sink due to increased harvest rates equals 2.0 and $7.2 \mathrm{Mt} \mathrm{C}$-eq. $\mathrm{yr}^{-1}$ and increase in HWP carbon stock equals only 0.3 and $0.9 \mathrm{Mt} \mathrm{C}$-eq. $\mathrm{yr}^{-1}$ for POL and MSY scenario. Consequently, the net flow of biomass-based carbon dioxide equivalent to the atmosphere is increased by 1.8 and 6.5 Mt C-eq. $\mathrm{yr}^{-1}$ in POL and MSY scenario compared to BAU. These figures can be compared to the development of the GHG emissions (excluding land use, land-use change and forestry, i.e. LULUCF sector) in Finland. In 2015, the GHG emissions in Finland were roughly 15 Mt C-eq., while the target in accordance with the National Energy and Climate strategy for 2030 is roughly $11 \mathrm{Mt}$ C-eq. and for 2050 less than 1-4 Mt C-eq. (TEM 2017). Thus, the increased net flow of biomass-based carbon dioxide equivalent to the atmosphere can negate a significant part of the efforts to reduce GHG emissions in other sectors.

Reduction in forest carbon equivalent net sink per increase in average wood harvested was lower between BAU and POL $\left(1.6 \mathrm{t}_{\mathrm{c} \text {-eq }} / \mathrm{t}_{\mathrm{c}}\right)$ than between BAU and MSY $\left(2.2 \mathrm{t}_{\mathrm{c}-\mathrm{eq}} / \mathrm{t}_{\mathrm{c}}\right)$ or between POL and MSY $\left(2.6 \mathrm{t}_{\mathrm{c} \text {-eq. }} / \mathrm{t}_{\mathrm{c}}\right)$. This indicates that increment loss of trees due to a reduction in NPP was higher the more wood was harvested.

It should be noted that in the international rules to account for and report GHG emissions by sources and removals by sinks, $\mathrm{CO}_{2}$ emissions from biomass combustion are considered as zero in the energy sector (IPCC 2019). This influences also the way how removals by forest carbon sink are defined in the IPCC accounting and reporting rules (IPCC 2019). As $\mathrm{CO}_{2}$ emissions from biomass combustion are accounted as zero in the energy sector, carbon removed in wood harvests is accounted as an emission and carbon stock increase in harvested wood products as a removal, both reported in Land use, land-use change and forestry (LULUCF) sector. This way the atmospheric balance between $\mathrm{CO}_{2}$ emissions and carbon sequestration remains the same than if physical flows of $\mathrm{CO}_{2}$ would have been the basis for biomass carbon accounting and reporting, such as in this study. Both of these methods are applicable and end up with the same conclusions but should not be mixed together. The results presented can be converted to follow the IPCC accounting and reporting rules by considering $\mathrm{CO}_{2}$ emissions from biomass combustion as zero, and forest and harvested wood product stock changes as an emission (decrease) or removal (increase). 


\subsection{Comparison with other studies}

Overall carbon balances of different forest management and biomass use scenarios at the national level in Finland have been studied by Soimakallio et al. (2016), Heinonen et al. (2017) and Seppälä et al. (2019). Changes in forest carbon stocks are based on the Motti model (Hynynen et al. 2015) in Soimakallio et al. (2016) and on the Monsu model (Pukkala 2011) in Heinonen et al. (2017) and Seppälä et al. (2019). Soimakallio et al. (2016) concluded that atmospheric $\mathrm{CO}_{2}$ is roughly neither increased nor decreased over a 100-year time horizon in forest utilization scenarios studied and that a large decrease is exceptionally unlikely. Even though the average avoided emissions were significantly higher in our study than in Soimakallio et al. (2016), the net $\mathrm{CO}_{2}$ flow to the atmosphere was higher in our study than in Soimakallio et al. (2016). This is mainly because our results indicate a significantly higher average reduction in forest carbon equivalent net sink per increase in wood harvested (mean values between 1.6 and $2.6 \mathrm{t}_{\mathrm{c}} / \mathrm{t}_{\mathrm{c}}$ ) than assessed in Soimakallio et al. (2016) (i.e. 0.4-1.1 $\mathrm{t}_{\mathrm{c}} / \mathrm{t}_{\mathrm{c}}$ ). Seppälä et al. (2019) concluded that atmospheric $\mathrm{CO}_{2}$ is increased when wood harvesting based on current forest management practices is increased over a 100-year time horizon using current displacement factors (on average $1.1 \mathrm{t}_{\mathrm{c}} / \mathrm{t}_{\mathrm{c}}$ ). In Seppälä et al. (2019), the average reduction in forest carbon net sink per additional wood harvested $\left(2.0-2.4 \mathrm{t}_{\mathrm{c}} / \mathrm{t}_{\mathrm{c}}\right)$ was within the range of our study. Heinonen et al. (2017) concluded that an annual harvest rate of $40 \mathrm{Mm}^{3}$ provided the highest climate change mitigation effect over a 90 -year time horizon within the range of annual harvests from 40 to $100 \mathrm{Mm}^{3}$.

Comparison of our results with Soimakallio et al. (2016), Heinonen et al. (2017) and Seppälä et al. (2019) provides two important insights. First based on the results presented by Heinonen et al. (2017) and Seppälä et al. (2019), lengthening the time horizon from 30 to 90 100 years does not significantly reduce net $\mathrm{CO}_{2}$ flow to the atmosphere resulting from increased wood harvesting and use. Second, the relatively low reduction in forest carbon net sink per increased wood harvested applied in Soimakallio et al. (2016) is thus explained mainly by changes in other forest management practices than in harvest rates.

Regarding forest carbon stock changes, Soimakallio et al. (2016) rely on four different Finnish national-level forest management scenarios over a 100-year time horizon presented in Hynynen et al. (2015). In 'The active forest sector and intensive biomass production (INT) scenario', they assumed intensified harvest rates and measures of intensive wood production, such as fertilization and artificial regeneration based on planting with genetically improved material. This scenario can be compared with their three other scenarios where less wood was harvested and wood production was less intensified. Based on the comparison, Soimakallio et al. (2016) showed that over 30 and 100 years, each unit of additional carbon harvested in INT scenario reduced forest carbon net sink by approximately 1.2 and 0.8 units of carbon $\left(\mathrm{t}_{\mathrm{c}} /\right.$ $\mathrm{t}_{\mathrm{c}}$ ). This is significantly less than the mean values (1.6-2.6 $\left.\mathrm{t}_{\mathrm{c}} / \mathrm{t}_{\mathrm{c}}\right)$ presented in Table 2 for the scenarios studied in this paper. Thus, although an extension of the time horizon considered lowers the reduction in forest carbon net sink per increased wood harvested, lower figures based on Hynynen et al. (2015) are mainly explained by consideration of forest management practices that compensate the effect.

Based on the results of our study, Soimakallio et al. (2016) and Seppälä et al. (2019), it is evident that increasing harvest rates increase atmospheric $\mathrm{CO}_{2}$ concentrations at least up to 100 years if current forest management practices and knowledge on avoided emissions are considered. These studies applied altogether three different forest models (MELA, Motti and Monsu) for different types of harvest and forest management scenarios and considered 
different factors for avoided emissions. The net biomass-based $\mathrm{CO}_{2}$ flow to the atmosphere can be reduced by applying measures to improve forest growth. Yet, according to Soimakallio et al. (2016), it is extremely unlikely that the net $\mathrm{CO}_{2}$ flow to the atmosphere would be significantly reduced by additional wood harvesting although measures of intensive wood production are considered. This conclusion can perhaps be reversed only if wood harvested could on average substitute significantly larger amounts of fossilbased $\mathrm{CO}_{2}$ emissions and if biomass-based $\mathrm{CO}_{2}$ emissions from wood harvested were significantly lower than is currently expected.

Soimakallio et al. (2016) studied carbon balances in six different scenarios using stochastic modelling. The amount of mechanical wood products, pulpwood products and energy products varies between those scenarios. However, Soimakallio et al. (2016) concluded that, given the parameter uncertainties, the carbon balances per wood entering the system were close to each other in all the scenarios studied and the parameter uncertainties were much higher than the variation between scenarios studied. This implies that forest industry structure alone did not significantly influence the avoided emissions.

The average displacement factor applied in our study was $1.2 \mathrm{t}_{\mathrm{c}} / \mathrm{t}_{\mathrm{c}}$ (range from 0.7 to $1.7 \mathrm{t}_{\mathrm{c}}$ ) $t_{c}$ ). This is close to that applied by Seppälä et al. (2019) and significantly higher than some other country-level displacement factors, such as those presented by Soimakallio et al. (2016) for Finland (0.4-0.8), Suter et al. (2017) for Switzerland (0.5 $\left.t_{c} / t_{c}\right)$, Lundmark et al. (2014) for Sweden (0.6) and Smyth et al. (2017) for Canada ( $\left.0.5 \mathrm{t}_{\mathrm{c}} / \mathrm{t}_{\mathrm{c}}\right)$. Increasing harvest of wood can show on average more than $1 \mathrm{t}_{\mathrm{c}} / \mathrm{t}_{\mathrm{c}}$ displacement factor typically only if a significant share of the increased harvest of wood is used for construction materials. In addition, the share of construction materials in the product mix heavily influence the longevity of products; thus, carbon flows to and from harvested wood products. The more pulp, paper and energy products are produced, the more likely the average displacement factor is less than $1 \mathrm{t}_{\mathrm{c}} / \mathrm{t}_{\mathrm{c}}$, and the more likely the carbon content of the products is rapidly released to the atmosphere.

\subsection{Uncertainties in forest carbon equivalent net sink}

Forest carbon net sinks are subject to relatively significant uncertainties. According to the most recent national GHG inventory (Statistics Finland 2019a), the total forest carbon net sink in Finland in 2017 is estimated to vary between 6 and $12 \mathrm{Mt} \mathrm{C}$-eq. This underlines the need to further improve forest carbon net sink estimation methods and especially those for soils that have the highest uncertainties. Regarding the development of forest carbon net sink in the future, even higher uncertainties take place even though the overall logging and total removals would be known.

We assumed $40 \%$ uncertainty and a strong positive correlation between the forest carbon net sink of the scenarios. The assumption on the strong positive correlation means that even though the absolute values of the forest carbon net sink were subject to significant uncertainty, this uncertainty influenced the same direction in each of the scenarios. Consequently, the uncertainty between the scenarios (Table 2) is much smaller in absolute terms. However, the strong positive correlation was based on the rough and simple assumption which should be justified by more comprehensive uncertainty analysis in further studies.

Climate change and the rise of atmospheric $\mathrm{CO}_{2}$ concentrations may significantly influence forest growth and soil respiration in the future. If these factors accelerate forest growth, the carbon net sink in forests may increase in absolute terms also in scenarios where harvest rates are increased from the current level (Kallio et al. 2016). However, this does not mean that the reducing impact additional harvests have on forest carbon net sink would be lower than in 
scenarios relying on the current climate conditions, such as those studied in this paper. Instead, the opposite may hold true. This is because the increased growth of existing forests also increases forgone carbon sequestration between more and less intensive wood harvesting scenarios (see supplementary information of Soimakallio et al. 2016).

In practice, climate change may influence differently in different types of forests, thus influencing the impact forest management has on the development of forest carbon stocks. Forests are prone to risks of different nature. The timing, frequency and severity of biotic (e.g. insects, parasites, pathogenic fungi) and abiotic disturbances (e.g. drought, wind, wildfire) are closely linked with climate. It is very likely that climate change will trigger not only direct changes in forest productivity, composition and diversity (Thuiller et al. 2005) but also indirect changes via modified disturbance regimes (Seidl et al. 2014; Temperli et al. 2013). Accordingly, disturbances have been found to increase in Europe's forests during the twentieth century (Schelhaas et al. 2003). Different forest types featuring different stand structure, composition and age under given climatic and management regimes have different resilience, i.e. capacity to withstand different disturbance agents. Brang et al. (2014) describe principles for reducing the effect of increasing disturbances on the carbon stocks. Increasing tree species richness improves stand resistance especially against droughts and storms, while the increase in structural diversity may decrease susceptibility for both abiotic and biotic disturbance agents, e.g. insects like bark beetle find saplings less attractive than mature trees. Natural regeneration maintains and increases genetic variation within tree species. Thus, from a forest management perspective, multi-layered mixed forest stands could be recommended if these principles together are accounted for. On the other hand, keeping average growing stocks low, especially in the MSY scenario, may support the resistance of individual trees due to lower stand density and at the same time, lower carbon density decreases the risk of a forest fire. We still lack an understanding of disturbance dynamics like interactions between different agents and scale-dependencies evolvement over time and in response to climatic change (Seidl et al. 2017).

It is evident that climate change increases the uncertainties related to forests. As far as climate change increases the growth of trees, reduction in forest carbon net sink due to increased wood harvests is strengthened. On the other hand, if natural disturbances likely increased by climate change can be reduced by increased wood harvests, then a reduction in forest carbon net sink due to increased wood harvests is weakened. Due to a lack of knowledge, it is difficult to conclude how the exclusion of climate change in our scenarios affects our results. Lack of knowledge on climate change impacts is not only related to the MELA model applied in this paper but a typical problem with other forest simulation models as well (Seidl et al. 2017).

\section{Concluding remarks}

According to our results, an increase in forest harvest rates in Finland certainly or very likely increased the overall GHG flows to the atmosphere over the 30-year time horizon and uncertainties considered. This was because the increased biomass-based $\mathrm{CO}_{2}$ and other greenhouse gas emissions to the atmosphere together with decreased carbon sequestration into the forest were very likely higher than the avoided fossil-based $\mathrm{CO}_{2}$ emissions. Increasing the share of long-living wood products increases the efficiency of how much fossil $\mathrm{CO}_{2}$ emissions can be avoided by the average unit of wood at one hand and increasing the carbon flow from forests to harvested wood product stock on the other hand. Even if all the biomass- 
based $\mathrm{CO}_{2}$ emissions from harvested wood could be eliminated, forgone carbon sequestration into forests due to increased harvests remains a critical issue which may hinder any climate benefits of increased wood utilization partly or totally over decades.

Funding Open access funding provided by Finnish Environment Institute (SYKE). S.S., A.L. and O.S. would like to thank the SOMPA project (decision number 312912 and 312933) funded by the Strategic Research Council of the Academy of Finland. S.S would also like to thank Kone Foundation for funding. T.K. gratefully acknowledge the project Climate Smart Forest Bioeconomy funded by Ministry of the Environment (VN/3046/ 2018).

Open Access This article is licensed under a Creative Commons Attribution 4.0 International License, which permits use, sharing, adaptation, distribution and reproduction in any medium or format, as long as you give appropriate credit to the original author(s) and the source, provide a link to the Creative Commons licence, and indicate if changes were made. The images or other third party material in this article are included in the article's Creative Commons licence, unless indicated otherwise in a credit line to the material. If material is not included in the article's Creative Commons licence and your intended use is not permitted by statutory regulation or exceeds the permitted use, you will need to obtain permission directly from the copyright holder. To view a copy of this licence, visit http://creativecommons.org/licenses/by/4.0/.

\section{References}

Äijälä O, Koistinen A, Sved J, Vanhatalo K, Väisänen P (eds) (2014) Forest management guidelines (in Finnish). Tapio publications

Anderson K, Peters G (2016) The trouble with negative emissions. Science 354(6309):182-183

Assmann E (1970) The principles of forest yield study: studies in the organic production, structure, increment and yield of forest stands. Pergamon Press, $506 \mathrm{p}$

Brang P, Spathelf P, Larsen JB, Bauhus J, Bončìna A, Chauvin C et al (2014) Suitability of close-to-nature silviculture for adapting temperate European forests to climate change. Forestry 87:492-503

Cowie AL, Brandão M, Soimakallio S (2019) Quantifying the climate effects of forest-based bioenergy. In Managing Global Warming (pp. 399-418). Academic Press

Field CB, Mach KJ (2017) Rightsizing carbon dioxide removal. Science 356(6339):706-707

Forest Europe (2015) State of Europe's Forests 2015 Report

Forster P, Ramaswamy V, Artaxo P, Berntsen T, Betts R, Fahey DW, Haywood J, Lean J, Lowe DC, Myhre G, Nganga J, Prinn R, Raga G, Schulz M, Van Dorland R (2007) Changes in Atmospheric Constituents and in Radiative Forcing. In: Climate Change 2007. In: Solomon S, Qin D, Manning M, Chen Z, Marquis M, Averyt KB, Tignor M, Miller HL (eds) The Physical Science Basis. Contribution of Working Group I to the Fourth Assessment Report of the Intergovernmental Panel on Climate Change. Cambridge University Press, Cambridge, United Kingdom and New York, NY, USA

Griscom BW, Adams J, Ellis PW, Houghton RA, Lomax G, Miteva DA, Schlesinger WH, Shoch D, Siikamäki JV, Smith P, Woodbury P, Zganjar C, Blackman A, Campari J, Conant RT, Delgado C, Elias P, Gopalakrishna T, Hamsik MR, Herrero M, Kiesecker J, Landis E, Laestadius L, Leavitt SM, Minnemeyer S, Polasky S, Potapov P, Putz FE, Sanderman J, Silvius M, Wollenberg E, Fargione J (2017) Natural climate solutions. Proc Natl Acad Sci 114(44):11645-11650

Gustavsson L, Pingoud K, Sathre R (2006) Carbon dioxide balance of wood substitution: comparing concreteand wood-framed buildings. Mitig Adapt Strateg Glob Chang 11(3):667-691

Heinonen T, Pukkala T, Mehtätalo L, Asikainen A, Kangas J, Peltola H (2017) Scenario analyses for the effects of harvesting intensity on development of forest resources, timber supply, carbon balance and biodiversity of Finnish forestry. Forest Policy Econ 80:80-98

Helin T, Sokka L, Soimakallio S, Pingoud K, Pajula T (2013) Approaches for inclusion of forest carbon cycle in life cycle assessment-a review. GCB Bioenergy 5(5):475-486

Hurmekoski E, Jonsson R, Korhonen J, Jänis J, Mäkinen M, Leskinen P, Hetemäki L (2018) Diversification of the forest industries: role of new wood-based products. Can J For Res 48(12):1417-1432

Hynynen J, Ojansuu R, Hökkä H, Siipilehto J, Salminen H, Haapala P (2002) Models for predicting stand development in MELA system. Finnish Forest Research Institute, Research papers 835 
Hynynen J, Salminen H, Ahtikoski A, Huuskonen S, Ojansuu R, Siipilehto J, Lehtonen M, Eerikäinen K (2015) Long-term impacts of forest management on biomass supply and forest resource development: a scenario analysis for Finland. Eur J For Res 134(3):415-431

IPCC (2014) Climate Change 2014. Synthesis Report Summary for Policymakers. http://www.ipcc.ch/

IPCC (2019) Frequently Asked Questions. Q2-10. Task Force on national Greenhouse Gas Inventories. https:// www.ipcc-nggip.iges.or.jp/faq/faq.html. Cited 30 December 2019

Kallio AMI, Salminen O, Sievänen R (2013) Sequester or substitute-consequences of increased production of wood based energy on the carbon balance in Finland. J For Econ 19(4):402-415

Kallio M, Salminen O, Sievänen R (2014) Low Carbon Finland 2050-platform: skenaariot metsäsektorille (in Finnish). Metlan työraportteja 308

Kallio AMI, Salminen O, Sievänen R (2016) Forests in the Finnish low carbon scenarios. J For Econ 23:45-62

Korhonen KT (2016) National forest inventories: assessment of wood availability and use: Finland. In: Vidal C, Alberdi I, Hernandez L, Redmond JJ (eds) National forest inventories : assessment of wood availability and use. Springer International Publishing, Switzerland, pp 369-384

Lappi J (1992) JLP: a linear programming package for management planning. Finnish Forest Research Institute, Research Papers 414. 134 p. Available at: http://urn.fi/URN:ISBN:951-40-1218-6

Lehtonen A, Salminen O, Kallio M, Tuomainen T, Sievänen R (2016) Skenaariolaskelmiin perustuva puuston ja metsien kasvihuonekaasutaseen kehitys vuoteen 2045. Selvitys maa- ja metsätalousministeriölle vuoden 2016 energia- ja ilmastostrategian valmistelua varten (in Finnish). Natural Resources Institute Finland, Natural resources and bioeconomy studies 36/2016

Lippke B, Oneil E, Harrison R, Skog K, Gustavsson L, Sathre R (2011) Life cycle impacts of forest management and wood utilization on carbon mitigation: knowns and unknowns. Carbon Management 2:303-333

Lovett GM, Cole JJ, Pace ML (2006) Is net ecosystem production equal to ecosystem carbon accumulation? Ecosystems 9(1):152-155

Luke (2018) The $12^{\text {th }}$ National Forest Inventory (NFI 12). Forest Resources are still increasing (in Finnish). Natural Resources Institute Finland (Luke), Press release 9 October 2018

Luke (2019a) Forest Resources of Finland. https://stat.luke.fi/sites/default/files/metsavarat_2019_en.pdf

Luke (2019b) Total roundwood removals by regional unit. Roundwood removals and drain of the growing stock. Structure and production Forest statistics Statistics database. Cited 28 December 2019

Luke (2020a). Forest industries' wood consumption 2018. Economy Forest statistics. Statistics database. Cited 19 November 2020

Luke (2020b). Production of sawn goods and wood-based panels $\left(1000 \mathrm{~m}^{3}\right)$. Forest industry. Forest statistics. Statistics database. Cited 19 November 2020

Lundmark T, Bergh J, Hofer P, Lundström A, Nordin A, Poudel B, Sathre R, Taverna R, Werner F (2014) Potential roles of Swedish forestry in the context of climate change mitigation. Forests 5(4):557-578

Minkkinen K, Laine J, Shurpali N, Mäkiranta P, Alm J, Penttilä T (2007) Heterotrophic soil respiration in forestry-drained peatlands. Boreal Environ Res 12:115-126

MMM (2019) National Forest Strategy 2025 - updated version. Publications of Ministry of Agriculture and Forestry 2019:17

Ojanen P, Minkkinen K, Alm J, Penttilä T (2010) Soil-atmosphere CO2, CH4 and N2O fluxes in boreal forestrydrained peatlands. For Ecol Manag 260:411-421

Ollila P (2017) Natural Resources Institute Finland. Private communication, 26 September 2017

Pingoud K, Pohjola J, Valsta L (2010) Assessing the integrated climatic impacts of forestry and wood products. Silva Fennica 44(1):155-175

Pöyry Management Consulting (2016) Suomen metsäteollisuus 2015-2035 (in Finnish). Loppuraportti X304203 [Finnish forest industry 2015-2035. Final report]. Available: https://tem.fi/documents/1410877/2772829/ P\%C3\%B6yry_Suomen+mets\%C3\%A4teollisuus+2015-2035.pdf/ac9395f8-8aea-4180-9642c917e8c23ab2. 62.p

Pukkala T (2011) Optimizing forest management in Finland with carbon subsidies and taxes. Forest Policy Econ 13(6):425-434

Redsven V, Hirvelä H, Härkönen K, Salminen O, Siitonen M (2013) MELA2012 Reference Manual (2nd edition). 2013. The Finnish Forest Research Institute. Available at: http://mela2.metla.fi/mela/julkaisut/ oppaat/mela2012_2nd_ed.pdf

Repola J (2008) Biomass equations for birch in Finland. Silva Fennica 42(4):605-624

Repola J (2009) Biomass equations for Scots pine and Norway spruce in Finland. Silva Fennica 43(4):625-647

Rockström J, Gaffney O, Rogelj J, Meinshausen M, Nakicenovic N, Schellnhuber HJ (2017) A roadmap for rapid decarbonization. Science 355(6331):1269-1271

Rüter S, Werner F, Forsell N, et al (2016) ClimWood2030 - climate benefits of material substitution by forest biomass and harvested wood products perspective 2030: final report. Johann Heinrich von Thünen-Institut, Braunschweig 
Sathre R, O’Connor J (2010) Meta-analysis of greenhouse gas displacement factors of wood product substitution. Environ Sci Pol 13(2):104-114

Schelhaas M-J, Nabuurs G, Schuck A (2003) Natural disturbances in the European forests in the 19th and 20th centuries. Glob Chang Biol 9:1620-1633

Seidl R, Schelhaas M-J, Rammer W, Verkerk PJ (2014) Increasing forest disturbances in Europe and their impact on carbon storage. Nat Clim Chang 4(9):806-810

Seidl R, Thom D, Kautz M, Martin-Benito D, Peltoniemi M, Vacchiano G, Wild J, Ascoli D, Petr M, Honkaniemi J, Lexer MJ, Trotsiuk V, Mairota P, Svoboda M, Fabrika M, Nagel TA, Reyer CPO (2017) Forest disturbances under climate change. Nat Clim Chang 7:395-402

Seppälä J, Heinonen T, Pukkala T, Kilpeläinen A, Mattila T, Myllyviita T, Asikainen A, Peltola H (2019) Effect of increased wood harvesting and utilization on required greenhouse gas displacement factors of wood-based products and fuels. J Environ Manag 247:580-587

Shukla PR, Skea J, Slade R, van Diemen R, Haughey E, Malley J, et al (eds.) (2019) Technical Summary. In: Climate Change and Land: an IPCC special report on climate change, desertification, land degradation, sustainable land management, food security, and greenhouse gas fluxes in terrestrial ecosystems [P.R. Shukla, J. Skea, E. Calvo Buendia, V. Masson-Delmotte, H.-O. Pörtner, D. C. Roberts, P. Zhai, R. Slade, S. Connors, R. van Diemen, M. Ferrat, E. Haughey, S. Luz, S. Neogi, M. Pathak, J. Petzold, J. Portugal Pereira, P. Vyas, E. Huntley, K. Kissick, M, Belkacemi, J. Malley, (eds.)]. In press

Sievänen R, Salminen O, Lehtonen A, Ojanen P, Liski J, Ruosteenoja K, Tuomi M (2014) Carbon stock changes of forest land in Finland under different levels of wood use and climate change. Ann For Sci 71:255-265

Siitonen M, Härkönen K, Hirvelä H, Jämsä J, Kilpeläinen H, Salminen O, et al (1996) MELA Handbook - 1996 Edition. Finnish Forest Research Institute, Research Papers 622

Smith P, Davis SJ, Creutzig F, Fuss S, Minx J, Gabrielle B, Kato E, Jackson RB, Cowie A, Kriegler E, van Vuuren DP, Rogelj J, Ciais P, Milne J, Canadell JG, McCollum D, Peters G, Andrew R, Krey V, Shrestha G, Friedlingstein P, Gasser T, Grübler A, Heidug WK, Jonas M, Jones CD, Kraxner F, Littleton E, Lowe J, Moreira JR, Nakicenovic N, Obersteiner M, Patwardhan A, Rogner M, Rubin E, Sharifi A, Torvanger A, Yamagata Y, Edmonds J, Yongsung C (2016) Biophysical and economic limits to negative CO 2 emissions. Nat Clim Chang 6(1):42-50

Smyth C, Rampley G, Lemprière TC, Schwab O, Kurz WA (2017) Estimating product and energy substitution benefits in national-scale mitigation analyses for Canada. GCB Bioenergy 9(6):1071-1084

Soimakallio S, Saikku L, Valsta L, Pingoud K (2016) Climate change mitigation challenge for wood utilization the case of Finland. Environ Sci Technol 50(10):5127-5134

Statistics Finland (2019a) GREENHOUSE GAS EMISSIONS IN FINLAND 1990 to 2017. National Inventory Report under the UNFCCC and the Kyoto Protocol. 15 April 2019

Statistics Finland (2019b) Appendix table 2. Energy use in manufacturing by industry 2018

Suter F, Steubing B, Hellweg S (2017) Life cycle impacts and benefits of wood along the value chain: the case of Switzerland. J Ind Ecol 21(4):874-886

TEM (2017) Government report on the National Energy and Climate Strategy for 2030. Publications of the Ministry of Economic Affairs and Employment Energy 12/2017. http://julkaisut.valtioneuvosto.fi/handle/ $10024 / 79247$

Temperli C, Bugmann H, Elkin C (2013) Cross-scale interactions among bark beetles, climate change, and wind disturbances: a landscape modelling approach. Ecol Monogr 83:383-402

Thuiller W, Lavorel S, Araújo MB (2005) Niche properties and geographical extent as predictors of species sensitivity to climate change. Glob Ecol Biogeogr 14(4):347-357

Tuomainen T, Regina K, Ollila P, Haakana M, Salminen O (2017) Land use sector in the EU 2030 climate and energy framework. Impacts of the proposal for a regulation COM(2016) 479 final on Finland. Natural Resources Institute Finland, Natural resources and bioeconomy studies 56/2017

Tuomi M, Laiho R, Repo A, Liski J (2011) Wood decomposition model for boreal forests. Ecol Model 222(3): $709-718$

UNFCCC (2015) Adoption of the Paris Agreement. Proposal by the President, 2015

Publisher's note Springer Nature remains neutral with regard to jurisdictional claims in published maps and institutional affiliations. 